\title{
Taxation of Individuals With Fluctuating Incomes
}

\author{
Adrian A. Kragen* and Jacques M. Adler**
}

$\mathrm{O}$

NE OF the purposes of the congressional hearing, before which a version of this Article was originally read, was to seek "greater equity through closer adherence to the principle that equal incomes should bear equal tax liabilities." This search necessarily involved a consideration of at least three sources of unequal treatment of taxpayers: (1) special privilege provisions, such as percentage depletion, which have the effect of increasing the tax burden on those not sharing in the privilege; ${ }^{2}(2)$ the special tax treatment of capital gains; ${ }^{3}$ and (3) the difference in tax burdens on equal incomes due to the timing of the receipt of the income. The following discussion is concerned with one aspect of the third basic source of inequality in our tax laws: where individuals, having over their lifetimes the same income subject to tax, have different tax burdens by reason of differences in the timing of receipt of that income.

The problem of the tax effect of sharp income fluctuation is not a new subject of concern to those who have been interested in perfecting our income-tax system. It has been considered by the committee before which this paper was originally read at nearly every one of its hearings on incometax revision ${ }^{5}$ and has been extensively discussed by economists, accountants, tax experts and others. ${ }^{6}$

* Shannon Cecil Turner Professor of Law, School of Law, University of California, Berkeley. This Article is based on a paper presented by Professor Kragen to the House Ways and Mcans Committee of the United States Congress. See Staff of tHe House Comsr. ON Ways and Means, 86ter Cong., 1st Sess., Compendiula of Papers on Broadentmg the Tax Base 579 (Comm. Print 1959).

** Member, Third-Year Class.

${ }^{1}$ Staff of House Comar. on Ways and Means, 86th Cong., 1st Sess., Coscpendiuly on Broadentng the Tax Base ix (Comm. Print 1959).

2 Id. at 933-1060.

3 Id. at 1193-1300.

1 Id. at $579-677$

5 See, e.g., Hearings on Topics Pertaining to the General Revision of the Internal Revenue Code Before the House Committee on Ways and Means, 85th Cong., 2d Sess. 2291 (1958); Hearings on Forty Topics Pertaining to the General Revision of the Internal Revenue Code Before the House Committee on Ways and Meants, 83rd Cong., 1st Sess. 243-300 (1953) ; Hearings on Proposed Revisions of the Internal Revenue Code Before the House Committe on Ways and Means, 80th Cong., 1st Sess. 11, 74, 1420, 1699, 1711 (1947).

6 Groves, Production, Jobs and Taxes 84-87 (1944); Atlas, Average Income and Its Use in Taxation, 13 Accountrng Rev. 124 (1938); Bravman, Equalization of Tax on All Individuals With the Same Aggregate Ineome Over Same Number of Years, 50 CoLUM. L. REv. 1 (1950); Cowing, Two Proposals for Averaging Income for Federal Income Tax Puaposes, 94 
Fundamentally the problem is one that arises from the combination of the annual accounting system ${ }^{7}$ and the highly progressive nature of our income-tax rate structure. ${ }^{8}$ When the income-tax rate extends from 20 to 91 percent of income received in a given period, a difference of a single day in the receipt of income can be extremely beneficial or expensive taxwise. ${ }^{\circ}$ It is clear that the combination of these two factors brings about substantial inequality of total tax burden. An individual does not close off his economic life on December 31 and start afresh on January 1 of the next year. Yet this is, for most taxpayers, the situation which the income-tax law assumes. This assumption, basically resulting from the need for revenue-regularity, ${ }^{10}$ causes us to ignore in the operation of the income-tax law real facts in the economic life of the individual and substitute instead the fictitious annual accounting system. Thus the happenstance of a client's failure to pay his fee before December 31 may mean substantial additional tax-cost to a lawyertaxpayer, or failure to send the bill prior to December 31 may mean substantial tax advantage.

The tax differential which may arise from tax receipt in one year or the next is of course materially expanded where one compares the tax burden of individuals whose income fluctuates over a long period with that of those whose income is without substantial change from year to year. Thus if we examine the case of an individual who for 20 years has a net taxable income of $\$ 5000$ eacl year, we will find an aggregate tax burden (assuming current income-tax rates remain stable) of $\$ 22,000$. However, if this total of $\$ 100$,000 (i.e., $\$ 5,000$ a year for 20 years) were earned in 10 years at $\$ 10,000$ net taxable income per year, the aggregate tax burden would be $\$ 26,400$ (or 20 percent more); and if earned in five years, would be $\$ 36,300$ (or 65 percent more).

If we examine the tax situation of an individual who has three high

J. Accovsitancy 586 (1952); Cowing, Would Averaging of Personal Income Over Period of Years be Desirable for Tax Purposes?, $93 \mathrm{~J}$. Accountaxcy 48 (1952); Dickerson, Averaging Income for Tax Purposes, J. Accountancy, May 1958, p. 27; Holt, Averaging of Income for Tax Purposes: Equaty and Fiscal-Policy Considerations, 2 NAT'x TAx J. 349 (1949); Latham, Tax Discrimination Against Lawyers, 26 Cac. S.B.J. 410 (1951); Steiger, Averaging Income for Tax Purposes: A Statistical Study, 9 Nax'x Tax J. 97 (1956); Tibbetts, The Accounting Period in Federal Income Taxation, 7 So. Econs. J. 362, 367 (1940-41); Vickrey, Averaging Income for Income-Tax Purposes, 47 J. Por. Ecos. 379 (1939); Woods, Taxation of Extraordinary Income, 33 TAxrs 353 (1955); Letter From J. S. Seidman to the Edlitor, 32 TAxas 206 (1954); Letter From J. S. Seidman to the Editor, 95 J. Accountancy 543 (19:53); Comment, 20 Wase. L. REv. 105 (1945).

7 INT. REv. CODE OP 1954, $\$ 441$.

8 INT. REv. CODE OP 1954, \&1.

- See Avery v. Commissioner, 292 U.S. 210 (1934); Commissioner v. Fox, 218 F.2d 347 (3d Cir. 1954); Estate of Richards v. Commissioner, 150 F.2d 837 (2d Cir. 1945). The development of the doctrines of constructive receipt and claim of right are further evidence of the importance of the timing of income.

10 Burnet v. Sanford \& Brooks Co., 282 U.S. 359, 365 (1931). 
income years in his total earning period as against that of one who, having the same aggregate earnings, has a steady unspectacular rise in net taxable income this discrepancy is even more noticeable.

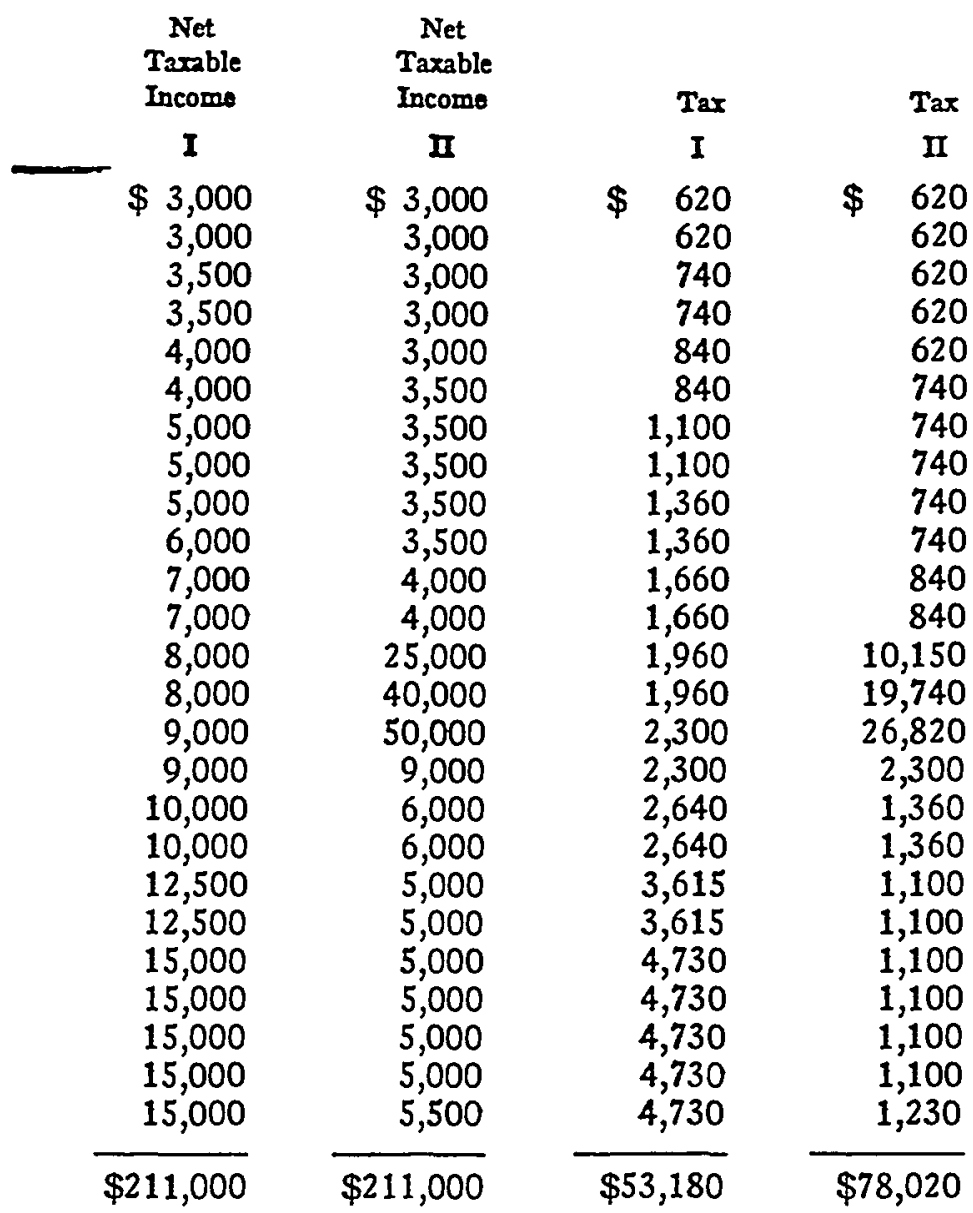

Without, for the moment, considering whether it is good or bad to have this tax differential, it cannot be questioned that, viewing the individual's lifetime as a tax unit, the fluctuation of net taxable income over the years will result in substantial inequality of tax treatment, and that this inequality will be found to be present at all tax-bracket levels from the lowest to the highest. The inequality, as previously noted, results primarily from the adoption as an essential of our income-tax system of the concept of annual accounting in order to meet the fiscal necessities of our Government. If we are to bring about some measure of equality in the instance we are here considering, we must either abandon the annual accounting concept, or devise some method which, within the framework of the annual accounting concept, offers at least some equalization. 
The annual accounting concept seems to be so imbedded ${ }^{11}$ as a basic principle of our tax-collection system that its abandonment is impractical in the light of the present financial need of our federal government. There have been many suggestions by writers for specific exceptions to the annual accounting method. Most of the suggestions which are intended for broad application involve the adoption of some form of lifetime or specified-period averaging of income. On the one hand, some of the formulas advanced would simply add another area of special treatment for some favored class of taxpayers to the many now available. ${ }^{12}$ On the other hand, although we would most nearly attain true tax equality by the elimination of all special privilege provisions, including exclusions, deductions and exemptions and the adoption of lifetime averaging, but even in such limited form as suggested by Professor Surrey ${ }^{13}$ it would seem utopian in concept. Certainly any such far-reaching change would be greeted by the contention that it would cause an economic upheaval of disastrous proportions, whether such prophecy is accurate or not. Realistically, the achievement of any such revision would be impossible and in some cases undesirable. ${ }^{14}$ Since certain pressure groups were sufficiently powerful to obtain special treatment from the Congress, there is little doubt that by uniting in defense of their accomplishments, they could block any attempts at wholesale repeal of all special deductions and exemptions. ${ }^{15}$

For the purpose of this discussion we assume that the realization of anything close to tax equality by this drastic type of revision is not possible at this time. There is, however, on a more specific level, an area of patent inequality which may be alleviated. Congress has already extended some relief in this area, but in a manner which even further emphasizes the unequal tax burden of those who do not qualify for that relief. We refer to

11 See United States v. Lewis, 340 U.S. 590,592 (1951) ; Burnet v. Sanford \& Brooks Co., 282 U.S. 359, 365 (1931).

12 Sce text at note 40 infra. Some of the special privilege scctions now in the Code are: INT. REv. CODE of 1954, $\$ \$ 37$ (credit for retirement income), 103 (interest on governmental bonds), 113 (exemption of mustering out pay), 151 (c), (d) (additional exemptions for aged and blind), 162 (expense accounts), 163-64 (deductions for interest and property taxes paid by home owners), 401-04, 421 (deferred compensation), 613 (percentage depletion), 1201, 1231 (capital gains), 1235 (sale of patents), 1301-06 (income attributable to several years). While the foregoing sections are for the benefit of relatively large groups of taxpayers, see also $\$ 1240$, commonly known as the "Mayer Amendment" since it was allegedly passed for the benefit of one man, Louis B. Mayer.

13 Statement of Stanley Surrey, Hearings on Topics Pertaining to the General Revision of the Internal Revenue Code Before the House Committee on Ways and Means, 85th Cong., 2d Sess. 2281, 2291 (1958).

14 The elimination of all personal exemptions, for example, would increase the number of returns filed each year and create a great administrative problem.

15 See Cary, Pressure Groups and the Revenue Code: A Requiem in Honor of the Departins Uniformity of the Tax Laws, 68 HARv. L. REv. 745 (1955); Wirtz, Govermment by Private Groups, 13 LA. L. REv. 440, 461 (1953). 
cases where fluctuating income from personal services results in an unequal tax burden and in many instances catapults the taxpayers involved into real financial chaos. Although the instances which have received the most public attention have been those concerning taxpayers engaged in the entertaiment industry - actors, musicians, and professional athletes-the problem is present in a broad section of occupations encompassing lawyers, authors, inventors, business executives, farmers and others. Congress has seen fit, as has been mentioned, to extend relief to some in these occupations. ${ }^{16}$ This relief varies in degree from the provisions of sections 1301 and 1302 of the Internal Revenue Code $^{17}$ to the special treatment for inventors in section 1235 of the Internal Revenue Code. ${ }^{18}$ The presence of ameliorative provisions for bunched income arising from specified personal services makes more evident how much "out in the cold" are those with equally bunched income from personal services, but not able to meet the criteria for relief. We can, of course, explain that tax relief to inventors is given to encourage the inventive genius necessary to our economy and that sections 1301 and 1302 only recognize that the services were not rendered entirely in the years in which the payment was received and thus mitigate a defect in the operation of the annual accounting system. It is difficult, however, to say that one who suddenly reaches an income peak after years of preparation and work is not entitled to the same aggregate net after taxes as is the inventor or author receiving the same gross income.

In the case of the entertainer who, after years of obscurity, rises suddenly and momentarily into the (financial) heights, the effect of his sudden affluence is frequently disastrous. To paraphrase the title of a popular play, "Will Success Ruin Rock Hunter?" It is, of course, simple to say in such a case that the taxpayer has at least 13 per cent $^{18}$ of his income left after federal taxes and that even this amount may well be more than he ever had before in his life. However, if we look at the situation realistically we will realize that other taxing agencies will take their share of his income and that in order to keep his place in the "kleig" or "arc" lights he is forced, or believes he is forced, to make abnormal and frequently nondeductible expenditures. If his monetary "glory" is of brief duration he may be faced

16 The present law permits some averaging of income. Note the carryback and carryover of losses in Internal Revenue Code of $1954, \S \S 172(\mathrm{~b}), 1212$, and the averaging permitted by \$§ 1301-06. The capital gains provisions are in reality an attempt to give preferred treatment to the realization of income which has accrued over a number of years. In addition, the deferred compensation, profit sharing, and retirement provisions, while they do not permit averaging do provide for the later receipt and taxation of present income.

17 These sections allow lawyers, authors, inventors and some others to have himited averaging of certain exceptional income fiuctuations.

18 Inventors are granted by this section a very favorable capital gains treatment of relatively long-term royalty payments.

19 INT. REv. CODE OE 1954, \& 1 (c). 
with a tax burden substantial enough to wipe hirn out and frequently leaving him a debt impossible to pay. ${ }^{20}$

The improvidence, the special requirements or other peculiar factors of this particular minority of taxpayers, would and should not concern us were it not that the next-door neighbor of this taxpayer, who has identical gross income received over a long period, can make the same expenditures and yet end up with substantial net assets because he will have paid as much as 50 percent less in federal income taxes. When we also realize that the author of the motion picture in which the actor appeared may have received the same amount of income at the same time and yet under Internal Revenue Code section 1302 be allowed to average income and pay substantially less $\operatorname{tax}^{21}$ we compound the shock arising from inequality of tax burden. There are many examples of the effect of this heavy burden, of which all of us have read in the newspapers and magazines. We should remember too that short-period high income is not confined to the entertainment industry; we can find similar although less spectacular situations in the case of automobile salesmen, real estate agents, department store buyers, lawyers and many others. Any one of these may well have a very low income year or years prior to or following a period of comparatively high income and experience the same distress as the more highly paid entertainer. In each of these cases as in the case of the entertainer the failure to spread the burden of the highly progressive tax rate has caused unequal treatment and the financial difficulty.

Eliminating unequal tax burdens is in itself a. worthwhile endeavor, but there is another outgrowth of this problem which makes the effort for reform important. Although representatives of entertainers and executives have urged that the present high rates have caused their clients to be less amenable to acceptance of employment with a resultant detrimental effect on the economy there is no real evidence that the tax burden has caused any substantial reluctance on the part of the highly paid individual to accept this remuneration. There is very clear evidence, however, that it has resulted in full employment for tax "experts" and that the ingenuity of these brethren has meant extended "self-help equalizing."22 It is obvious that the Treasury Department has been engaged in constant efforts to find an answer

${ }^{20}$ See When the Tax Collector Takes Everything ..., U.S. News \& World Report, June 15, 1959, pp. 121-24.

21 Provided, of course, that the author himself can qualify. He must have worked on the particular item for at least 24 months and must receive $80 \%$ of all payment for his work in respect of such item within the taxable year, previous taxable years, and the succeeding 12 months. INT. REv. CODE OF 1954, \$\$ 1302(a) (2),(3).

22 Commissioner v. Gross, 236 F.2d 612 (2d Cir. 1956); Herhert v. Riddell, 103 F. Supp. 369 (S.D. Cal. 1952); Julius Marx, 29 T.C. 88 (1957); Pat O'Brien, 25 T.C. 376 (1955); Jack Benny, 25 T.C. 197 (1955) acq., 1959 INt. Rev. Buzr. No. 40, at 7; Fred MacMurray, 21 T.C. 15 (1953). 
to the devices and "gimmicks" of tax reduction and tax postponement which have been utilized. Thus it is clear that the heavy tax burden imposed upon actors, directors and builders, stemming from the tremendous tax differential depending on whether income received is ordinary income or capital gain, was the major reason for the development of the "single shot" corporation and therefore for its legislative antidote, the complicated and cumbersome collapsible corporation provisions of Internal Revenue Code section $341 .^{23}$ We have seen other provisions enacted in our tax laws which make it more difficult to understand and administer than need be, simply because of the presence of this unequal and the heavy tax burden. Today we have numerous methods (or devices or "gimmicks" if these terms are more apt in the particular case) designed to reduce the tax burden of the high-income taxpayer. The fundamental intent of these is not to obtain equality but rather to reduce tax to as low a level as possible. If these methods are as successful as their creators hope, the result will be that the inequities will be shifted and the greater share of the tax burden will fall on the taxpayer having stable income. Thus we have deals involving multiple incorporations, ${ }^{24}$ independent productions, ${ }^{25}$ deals stipulating the use of foreign corporations, ${ }^{28}$ foreign residence, ${ }^{27}$ cattle deals, ${ }^{28}$ oil deals, ${ }^{29}$ and many others. These ventures are usually handled in ways not normal in the economy, distorting the economic picture and the tax laws at one and the same time. If we were able to bring some relief to the bunched-income taxpayer we would remove much of the incentive to search out tricky and uncertain methods of tax relief. This relief, of course, should at the same time give closer equality of treatment to any taxpayer who has "bunched" income, whether it be in the 20-percent or the 91-percent bracket.

There would appear to be two possibilities which offer at least some relief to the individual with bunched income. If we are to consider only the "flash in the pan" situation in which an individual has only sporadic periods of "excessively" large income, one solution would seem to be a further onslaught on the annual accounting concept by the use of one of the methods of averaging income.

23 INT. REv. CODE of 1954, §341. See particularly § $341(e)$. See also, Modrall, Collapsible Corporations and Subsection (e), 37 Taxes 895 n.n.2, 3 (1959).

24 To avoid surtax and some personal holding company problems.

25 To permit more advantageous use of pension plans, income-tax rates at lower corporate levels, and, if $\S 341$ can be avoided, conversion of ordinary income into capital gains.

${ }^{26}$ See, e.g., Weissman, Tax Advantages of the Netherlands Antilles for Motion Picture Companies, 32 So. CaI. L. Rev. 391 (1959).

2i To take advantage of INT. REv. CODE of 1954, $\$ 911$.

28 See, e.g., Diamond A. Cattle Co. v. Commissioner, 233 F.2d 739 (10th Cir. 1956).

29 See, e.g., Commissioner v. P. G. Lake, Inc., 356 U.S. 260 (1958). Percentage depletion also makes this type of investment attractive. 
Primarily, three types of averaging have been proposed: the simple average, the moving average and the progressive average. ${ }^{30}$

The simple average merely sets a period over which income will be averaged. Usually in proposals made for its use this period is set by law, ${ }^{31}$ but use of the provision is the subject of an election by the taxpayer at the close of the period, and the election is seen as being made at the close of a year of peak income. The income of any year included in the averaging period is not again used in any subsequent averaging period. This method is obviously the simplest for the taxpayer and probably for the Treasury. Canada is presently using this system for farmers and fishermen. ${ }^{32}$

The moving average uses a specified number of prior years to average in with the current year and these produce the measure of the tax.$^{33}$ Under this method the same year may enter into the averaging computation more than once. This system has been used without real success ${ }^{34}$ in England, ${ }^{35}$ Australia ${ }^{36}$ and in the United States, in Wisconsin. ${ }^{37}$ However, it remains in use in Australia for special groups. ${ }^{38}$ The writer has no information on its success, but its retention would appear to be some indication thereof. In a few exceptional instances under present law a variation of the moving average is possible in connection with section 1302 of the Internal Revenue Code. The main problems of the moving average are the complications of record-keeping involved and, if its use is not entirely optional with the taxpayer, the potential of heavy payments in low income years.

30 Bravman, Equalization of Tax on All Individuals With the Same Aggregate Income Over Same Number of Years, 50 Colum. L. Rev. 1, 6 (1950); Cowing, Would Averaging of Personal Income Over Period of Years Be Desirable for Tax Purposes?, $93 \mathrm{~J}$. Accountancy 48, 49 (1952) ; Comment, 20 Wast. L. REv. 105, 107 (1945).

31 Groves, Production, Jobs and Taxes 85 (1944); Dickerson, Averaging Income for Tax Purposes, J. Accovitaxcy, May 1958, pp. 27, 30; Statement of Thomas N. Tarleau, Hearings on Proposed Revisions of the Internal Revenue Code Before the House Committee on Ways and Means, 80th Cong., 1st Sess. 1711, 1713 (1947).

32 Cas. Rev. Stat. c. 148, \& 42 (1952).

33 For example, if a 5-year moving average were used, the tax for the year 1960 would be based on the amount of income earned in the period 1956 to 1960 , divided by five. The tax for the year 1961 would be based on the amount of income earned from 1957 to 1961, divided by five.

${ }^{34}$ Atlas, Average Income And Its Use in Taxation, 13 Accountring Rev. 124, 130 (1938).

35 Such provisions were enacted from time to time hetween 1799 and 1918: 39 Geo. 3, C. 13, $\$ 79$ (1799); 39 Geo. 3, c. 22, Schedule A, 9th, 10th, 15th Cases (1799); 43 Geo. 3, c. 122, Schedule D (1803); 5 \& 6 Vict., c. 35, \& 100, Schedule D, Rules Applicable to 1st Case (1842); 16 \& 17 Vict., c. 34, \& 48 (1853); Income Tax Act, 1918, 8 \& 9 Geo. 5, c. 40, 1st Schedule, Schedule D, Rules Applicable to Case I. All averaging was repealed by the Finance Act, 1926, 16 \& 17 Geo. 5, c. $22,829$.

36 Averaging came to Australia in 1922. Income Tax Assessment Act, No. 37 of 1922, $\$ 13$ (Austl.).

37 Wis. Laws 1927, ch. 539, as amended, Wis. Laws 1928, ch.4. All averaging in Wisconsin has been repealed. Wis. Laws 1931, ch. 448.

38 Income Tax \& Social Services Contribution Assessment Act, 1936-1958, §\$ 149-58E (Austl.). 
The progressive average is essentially a union of the simple average and moving average notions. As with the moving average, there is final determination of tax liability for each year. But, the calculation is similar to that made in the case of the simple average. The taxpayer determines what his average income is and what the tax would have been had the average income been earned in each year. He then determines the present value, including interest, of taxes already paid and the value, again including interest, of taxes which would have been payable had the average income been earned in each year. The difference between these two figures determines the amount of the taxpayer's current liability or credit. The progressive average notion has some notable support, ${ }^{39}$ but it seems unduly complicated.

The systems as proposed in articles and discussions vary in detail: length of time set for the averaging period, specific restrictions on use, and taxpayers affected. The proponents of all these systems appear to have one idea in common, i.e., that the use of the averaging provision should be optional with the taxpayer. This seems somewhat incongruous to the writers. If we are seeking equality, then the taxpayer should not have an option that allows him to pay less tax than that required by the operation of the annual accounting principle and then, in a subsequent period when averaging would require more tax than use of annual accountmg, to reject averaging. This provision would give the taxpayer the "best of all possible worlds" treatment, a treatment which he is always seeking, but which was the basis for criticism of such sections as Internal Revenue Code sections 1231 and 1235. Rather, it would appear to the writers that averaging, once adopted, should be compulsory in any period in which there was substantial net taxable annual income variation with, however, a provision allowing the taxpayer to show that the use of averaging subjects him to an unequal burden. ${ }^{40}$

There are defects and difficulties in the use of any one of the proposed methods of averaging. Any averaging system superimposed on the pyramid of exemptions and deductions will make for very difficult problems of adjustment. We have, however, made these adjustments without noticeable upheaval in relation to such special sections as Internal Revenue Code section 1301, and we must assume we could do so equally well under the proposed expansion of that system.

We would, therefore, suggest the following formula: (1) There should

39 Bravman, Equalization of Tax on All Individuals With the Same Aggregate Income Over Same Number of Years, 50 CoLvx. L. REv. 1, 10, 27 (1950); Vickrey, Averaging Income for Income-Tax Purposes, 47 J. PoL. Econ. 379 (1939).

40 The Commissioner could be empowered to relieve extreme situations as, for instance, where a taxpayer has had only two high-income years in a period of 10 years, but is required to include both in one averaging period. The Commissioner might relieve harsh situations by lengthening the averaging period or by using a particular year in more than one calculation. 
be a 5-year averaging period. The taxpayer would be precluded under this system from using any year more than once in the cletermination of the average. (2) In order to avoid administrative burdens there should be no averaging at all unless, during the original or any subsequent 5 -year period, at least one of the 5 years has 50 percent more net taxable income than some other year within the period. (3) Averaging should be mandatory in any case where the taxpayer has initially elected averaging.

The period suggested, is of course, wholly arbitıary, and it may be that 3 years or 7 years or some other period would be more feasible administratively and would arrive at a more equitable result for the taxpayer. The 50 percent figure is equally arbitrary and intended only to confine the operation of the section to the more patent cases of inequity and thus limit both loss of revenue and administrative problems. The provision would, however, still affect instances of rising income not sharply peaked. Thus an individual starting in 1960 with $\$ 5000$ annual income and rising by 1964 to $\$ 7500$ would be entitled to use the section. The section would not, however, be usable by such individual in the form suggested if his income never goes below $\$ 5000$ or above $\$ 7499$ in the period.

This proposal envisages a system similar to the one in use in Canada for farmers, and fishermen, but with changes. The Canadian law makes use or nonuse for any period entirely optional with the taxpayer, ${ }^{41}$ and there is no lower limit on the extent of income fluctuation which will entitle the taxpayer to qualify for use of the section.

This formula, we believe, would offer substantial relief to a large group of taxpayers. It should be noted, however, that although it would offer some aid to the taxpayer who has an extended period ( 5 or 10 years) of very high earnings, it would give them no real equalization. For example, if an individual has net taxable income for 5 years of $\$ 2000$ a year, then for 10 years of $\$ 32,000$ a year, and then for 10 years of $\$ 6000$ a year, his tax under the present system (assuming the present tax rates continue for the entire period) would be $\$ 160,200$. If he started averaging under the proposed formula in the sixth year he would still have a total tax bill of $\$ 150$,920 , whereas a stable income flow accumulating the same aggregate over the 25-year period by a net taxable income of $\$ 15,600$ a year would result in an aggregate tax bill of $\$ 125,300$ or about five-sixths of the amount paid by the bunched-income taxpayer even with averaging.

This averaging provision, as noted, will not give complete relief to the taxpayer whose high income, though bunched, continues for a relatively long period. Therefore he will continue the search for various methods to bring his tax load within one of the special-privilege provisions or will make 
artificial changes in the time of receipt to bring the income within a lower tax bracket. For this reason a second proposal is made, aiming at equalization and consequent reduction of the use of tax-saving devices.

Undoubtedly one of the most prevalent of these devices is the deferredcompensation agreement. These agreements generally provide that income for services rendered, in 1959 for example, will be paid in installments over a number of subsequent years. The agreement in respect of "Bridge on the River Kwai" made by William Holden, commented upon in Time, ${ }^{42}$ is a very extreme version of such agreements. Deferred-compensation agreements are, however, extensively, if less spectacularly, used in all industries, and there undoubtedly are hundreds of millions of dollars now owed by employers of all descriptions under such agreements. The Treasury has made a number of attacks on such agreements, ${ }^{43}$ but these have been unsuccessful ${ }^{44}$ so long as the payment of the debt was not secured.

These agreements are generally unsatisfactory to the employee because he is required to gamble on the continued solvency of the employer. Frequently he also binds himself by non-competition clauses, agreements to render advisory services and other so-called contingencies. However, employees accept such agreements with all their defects as being better than full present payment subject to the impact of the progressive tax rate. There seems to be little doubt but that unless the use of these agreements is deterred by statutory or judicial mandate their number will increase. There is no need to point out that these agreements are intended to and normally do reduce tax revenue. Therefore, both to give a more effective and satisfactory remedy to taxpayers now utilizing such agreements and to minimize the adverse revenue effects of such agreements, some action should be taken.

One solution to this problem which has been suggested ${ }^{45}$ is to couple the deferment of income from personal services with a requirement that the deferred amounts as earned by the employee shall be paid by the employer to the Treasury Department which, in turn, will issue noninterestbearing, nontransferrable certificates to the employees. The amounts would not be taxed to the employee until the year of withdrawal, and in that year they would be included in gross income. In order to secure in some part the ultimate tax, there could be a withholding on withdrawal of such an amount of federal income tax computed as if the withdrawal were the taxpayer's entire net taxable income for the year. In the event of death

42 June 2, 1959, p. 84.

43 E.g., Sproull v. Commissioner, 194 F.2d. 541, (6th Cir. 1952), affirming per curriam 16 T.C. 244 (1951).

44 Commissioner v. Oates, 207 F.2d 711 (7th Cir. 1953).

45 This is an idea which arose among some of the practitioners in the field of deferred compensation. 
prior to withdrawal the certificates would be considered income in respect to a decedent under Internal Revenue Code section 691 .

A plan of this type would be advantageous to the taxpayer because it would relieve him of the present uncertainties of deferred-compensation agreements while retaining the advantages of equalizing tax impact and building a fund which would assist him in lean years, thus having at least some aspects of a retirement plan. It would be advantageous to the Government because it would provide substantial amounts of interest-free money and would materially reduce the use of undesirable and uncontrolled tax-saving devices. Thus, if allowing such deferment affected the revenue to any real extent, that effect could be substantially offset by the interest-free use of the deferred amounts. ${ }^{48}$

Over the last 10 years we have heard expressions of increasing discontent with our tax laws. Even those who vehemently support the system admit its glaring weaknesses. In focusing on the asserted inequalities in tax burdens as a subject of study, the committee before which a version of this Article was originally read ${ }^{47}$ selected for investigation a major cause of discontent with our income-tax law. The ideal solution of the problems of inequality might involve, as suggested earlier, a complete elimination of all of the special privileges, deductions and exemptions. More realistically, such a solution has to be rejected, to be reserved for the time most of us will never see again when revenue needs will have been materially reduced. We can, however, acquiesce in the justice of some criticisms and achieve a needed reform by adopting measures to relieve that inequality of tax burdens caused solely by our annual accounting concept. It is believed the plans suggested herein will do so. They do not involve the introduction of substantial additional complexity into the tax laws, and they may reduce the need for the devising of new statutory methods to combat tax-expert ingenuity.

46 Some averaging aspects can be added to the provision by restrictive requirements as to deposit and withdrawal percentages.

${ }^{47}$ See introductory note to this Article supra. 